\title{
Development History and State-of-the-art of Laser Ceramics
}

\section{Ha-Neul Kim ${ }^{1 \dagger}$, Jae-Woong Ko ${ }^{1}$, Young-Jo Park ${ }^{1 \dagger}$, Hyeon-Myeong Oh ${ }^{1,2}$, Hyun-Kwuon Lee ${ }^{2}$}

${ }^{1}$ Engineering Ceramics Research Group, Korea Institute of Materials Science, Changwon 51508, Republic of Korea ${ }^{2}$ School of Advanced Materials Science and Engineering, Kumoh National Institute of Technology, Gumi 39177, Republic of Korea

\section{레이저 발진용 투명세라믹의 발전사 및 국내/외 연구 동향}

\author{
김하늘 ${ }^{\dagger}$, 고재웅, 박영조 ${ }^{1 \dagger}$, 오현명,2, 이현권 ${ }^{2}$ \\ 1한국기계연구원 부설 재료연구소 \\ 금오공과대학교 신소재공학부
}

(Received August 17, 2020; Revised August 31, 2020; Accepted September 3, 2020)

\begin{abstract}
s
The most valuable application of transparent ceramics is the laser crystal for the solid-state laser. Especially, since a large-area laser crystal cannot be realized by the single crystal due to the inhomogeneous segregation of laser generating element, the transparent ceramics is considered as the most appropriate material for the high intensity solid-state laser system. In order to generate the laser from the transparent ceramics effectively, it is necessary to remove every single pore for the nearly theoretical inline transmittance as well as to make the ceramics highly durable against the thermal shock induced by heat generation. In this article, while briefly looking back on the global development history of solid-state lasers, we would like to discuss the recent trend of research on transparent ceramics for the solid-state laser in Korea and the direction of future technology development.
\end{abstract}

Keywords: Transparent, Ceramics, Solid state laser, Laser, Yttria

${ }^{\dagger}$ Corresponding Author: Ha-Neul Kim, Young-Jo Park

E-mail: skykim@kims.re.kr, yjpark87@kims.re.kr 


\section{특 집 표 김하늘, 고재웅, 박영조, 오현명, 이현권}

\section{1. 고체 례이저의 발전사와 투명셰라믹의 필요성}

투명한 고체 결정체는 결정구조 및 전자 축조에 따라 구성되는 에너지 밴드에 따라 특정한 파장의 빛을 흡수 하고 내부의 전자가 여기(excitation)-방출(emission) 되는 특징을 가질 수 있다. 이런 특성을 적극적으로 활 용하기 위해 오랜 기간 연구를 통해 발현한 것이 최초의 레이저인 루비(Ruby, $\mathrm{Cr}$-doped $\mathrm{Al}_{2} \mathrm{O}_{3}$ single crystal) 레이저이다. ${ }^{1)}$ (Fig. 1)

1960년에 최초로 발견된 레이저를 무기화 하기 위해 강대국들은 즉각적인 개발에 돌입하였는데, 1965년 소 비에트 연방에서 최초의 레이저 대포 개발 연구를 시 작하였다. 1985년 미국과의 군비경쟁으로 인한 재정 악화로 레이저 무기 개발이 중단될 때까지 $\mathrm{Nd}$-인산염 (phosphate) 유리 및 이산화탄소 $\left(\mathrm{CO}_{2}\right)$ 를 광원으로 하 는 레이저 무기를 비행기, 전투함에 탑재하여 실증 테스 트까지 마치는 등 선구적인 연구개발을 수행하였다. 냉 전 종식 이후에는 이스라엘과 미국이 공동으로 헤즈불 라의 로켓탄 요격을 위해 1996년 전술 고에너지 레이저 (Tactical High-Energy Laser, THEL) 개발에 본격적 인 연구개발에 착수한 이래로, 2000년대 초반에 휴대용 전술 고에너지 레이저(Mobile THEL), 현재의 고에너지 레이저 전술차량(High Energy Laser Tactical Vehicle Demonstrator, HEL TVD) 개발로 이어지면서 실제 전 투에서 사용가능한 레이저 무기를 점점 현실화시키고 있다. ${ }^{2}{ }^{\text {(Fig. 2) }}$

무기로 사용 가능한 레이저를 개발하기 위해서는 시 스템의 소형화가 필요하였으며, 따라서 고출력의 화학 레이저, 유리 레이저 등은 소형화가 불가능하기 때문에

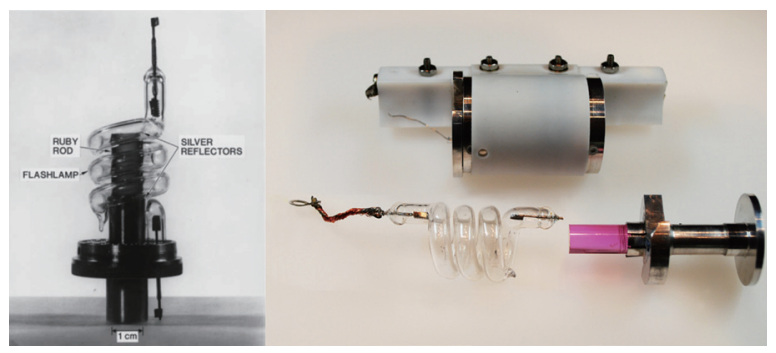

Fig. 1. 세계 최초 루비 레이저의 실제 모습 ${ }^{1)}$
점점 개발 방향이 소형화된 고출력 고체 레이저로 진행 되어 왔다. 미국 국방성은 실전에 적용하여 치명적인 타 격을 줄 수 있는 에너지를 $100 \mathrm{~kW}$ 이상으로 판단하였 으며, 2000년도에 Stanford 대학교의 Rutherford 등 은 $82 \mathrm{~mm} \mathrm{X} 129 \mathrm{~mm}$ 면적의 슬라브(slab) 형태의 고 체 광원이 있으면 $100 \mathrm{~kW}$ 레이저를 제조가능하다는 중 요한 연구를 발표하였다. ${ }^{3)}$ 당시에 $100 \mathrm{~kW}$ 고체 레이 저 시스템을 현실화하기 위해서는 $200 \mathrm{~mm}$ 이상의 큰 $\mathrm{Yb}: Y A G(Y t$ trium Aluminum Garnet) 단결정이 필 요하다고 계산되었으나, 제조 공정 상의 한계로 인해 $200 \mathrm{~mm}$ 급 단결정은 제조가 불가능하기 때문에 제조 시 크기에 제약이 거의 없는 다결정 YAG 투명세라믹의 필요성이 크게 대두되었다.

투명세라믹으로 레이저 발진이 가능하기 위해서는 단 결정과 동등한 수준, 즉 이론치에 근접한 광투과율을 가 져야 하는데, 최초의 토기가 기원전 27000년에 만들어 진 이래로 아주 오랜 시간의 기술축적이 되고 나서야 세 라믹의 투명화가 실현되었을 정도로 세라믹의 투명도를 높이는 것은 고난도의 기술이다. 레이저 발진이 어려운 것은 투명세라믹 내에 기공(pore)이 $0.1 \%$ 만 잔류해도 발진이 거의 되지 않기 때문이다. ${ }^{4)}$ (Fig. 3) 원료를 용융 시켜서 액체로 만들고 굳히는 방식인 유리(glass)나 단 결정(single crystal)의 경우에는 기공 제거가 쉽지만, 분말을 원료로 하여 소결과정 만으로 제조하는 세라믹 의 경우 기공의 완전한 제거의 어려움으로 인해 투명하 게 만들기 어렵다. (Fig. 4) 이 때문에, 1995년이 되어서 야 레이저 발진이 가능한 광투과율을 가지는 Nd:YAG 투명세라믹이 비로소 개발될 정도로 기술 성숙이 최근 에 이루어지고 있는 형편이다. ${ }^{5)} 2002$ 년 일본에서 단결


Fig. 2. 미국이 개발 중인 고에너지 레이저 전술차량 (High Energy Laser Tactical Vehicle Demonstrator, HEL TVD)2) 


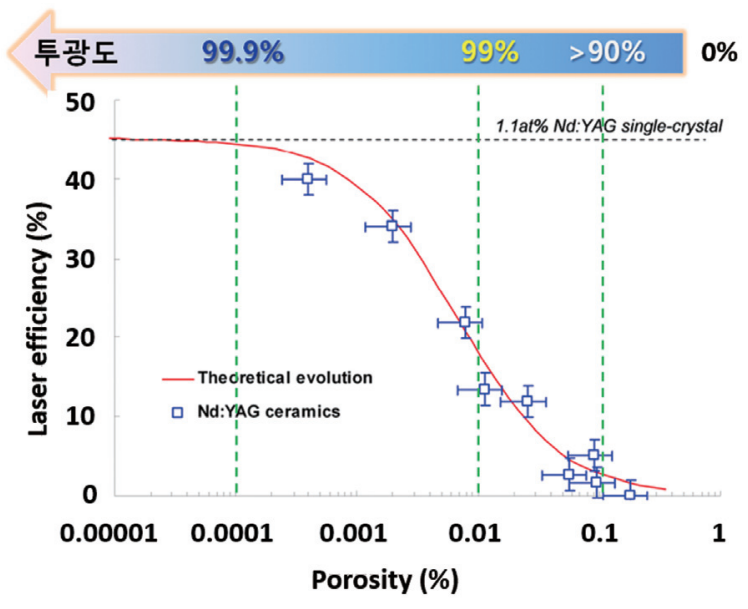

Fig. 3. 투명세라믹 내부의 기공 함유량/투광도와 레이저 발진 효율 의 관계 ${ }^{4)}$

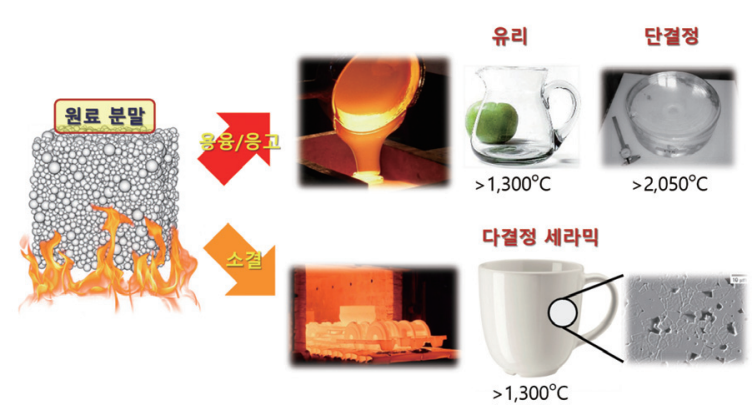

Fig. 4. 투명한 유리/단결정 대비 투명한 세라믹 제조의 어려움

정과 동등한 수준의 발진 효율을 가진 $\mathrm{Nd:YAG} \mathrm{투명세}$ 라믹이 개발되면서 고체 레이저 무기 적용에 큰 이정표 가 세워졌고 ${ }^{6)}$, 일본의 Konoshima Chemical은 공정의 개선을 통해 $150 \mathrm{~mm} \mathrm{X} 150 \mathrm{~mm}$ 면적의 슬라브 Nd:YAG 투명세라믹 소재를 개발함으로써 2010년에 미 국방성이 사상 최초로 $105 \mathrm{~kW}$ 급 Nd:YAG 레이저 무기의 시험가 동에 성공할 수 있는 큰 이정표를 마련하였다. ${ }^{7)}$

다만, 그 이후에 세라믹 고체 레이저를 구성하는 광학 계의 환경 민감도가 높은 이유로 인해 진동 및 하중 인 가가 빈번한 전술차량용 무기(HEL TVD)에는 부적합하 다는 결론에 도달하여, 현재의 레이저 무기 개발은 광섬 유 다발을 적용한 파이버 레이저(Fiber laser) 또는 웨 이브가이드 레이저(Waveguide laser) 개발로 방향성이



Fig. 5. 미국 국립점화시설에서 사용하는 $\mathrm{Nd}$-인산염 유리 ${ }^{8)}$

바뀌었다. 그로 인해 슬라브 형태의 대면적 투명세라믹 을 적용하는 레이저 무기 개발은 중단된 상태이다.

그럼에도 불구하고, 투명세라믹은 여전히 메가와트 (MW)급 이상의 초고출력이 요구되는 고정식 레이저 시 스템의 간소화에는 여전히 매력적인 소재로 여겨지고 있다. 대표적인 예시로, 미국의 국립점화시설(National Ignition Facility, NIF)을 들 수 있다. ${ }^{8)} \mathrm{NIF}$ 는 $\mathrm{Nd}$ :인 산염 유리를 레이저 광원으로 적용하여 192개의 빔을 동시에 조사하는 방법으로 수소 핵융합을 구현하기 위 해 2009년 완공된 시설이다. 여기에 사용되는 $\mathrm{Nd}$ :인산 염 유리의 크기는 사람의 키보다 크고(Fig. 5) 열전도도 가 $0.78 \mathrm{~W} / \mathrm{mK}$ 로 매우 낮은 수준이므로 1 회 발진 후 발 열된 유리를 냉각시키는데 시간이 많이 필요하여 4시간 에 1 회만 발진이 가능한 비효율적인 시설이다. 이를 초 당 5회 수준으로 발진시키기 위해서 열전도도가 10W/ $\mathrm{mK}$ 를 초과하고, 단위면적 대비 레이저 발진 효율이 우 월하여 시스템 크기도 간소화시킬 수 있는 $\mathrm{Nd:YAG}$ 투 명세라믹의 적용을 지속적으로 추진하고 있다. 유럽에 서도 레이저 입자가속 암 치료기, 대면적 표면처리장치, 고해상도 영상장치 등의 현실화를 위해 HiLASE(High average power pulsed LASErs), HiPER(High Power laser Energy/Research), ELI(Extreme Light Infrastructure) 등의 대형 프로젝트가 진행되고 있으 며, 이 때 적용해야 하는 초고출력/고반복 고체 레이저 를 개발하기 위해 슬라브 형태의 대면적 $\mathrm{Yb}: \mathrm{YAG}$ 투명 세라믹을 적용하는 연구가 활발히 진행되고 있다. ${ }^{9-10)}$ 


\section{특 집 표 김하늘, 고재웅, 박영조, 오현명, 이현권}

\section{2. 투명한 셰라믹의 개념 및 결정인자}

세라믹이 투명하다는 개념에 대해 직관적인 이해를 돕는 모식도를 Fig. 6에 나타내었다. 어떤 세라믹이 투 명하기 위한 필수조건으로 가시광선을 통과시킬 수 있 는 밴드 갭(3.26eV) 이상을 가져야 한다. 이때, 세라믹 의 내부에 가시광선의 산란을 일으키는 요인이 없는 경 우에 세라믹 뒤쪽의 형상이 왜곡되지 않고 선명하게 보 이는 상태를 투명하다고 표현한다. 세라믹의 내부에 산 란을 시킬 수 있는 요인이 존재하나 많지 않을 때는 세 라믹 뒤쪽의 형상이 보이긴 하지만 흐릿하게 번지는데, 이를 반투명하다고 표현한다. 세라믹 내부에 가시광선 을 산란시키는 요인이 많이 존재하면 세라믹 뒤쪽이 보 이지 않으며, 이를 불투명하다고 표현한다. 세라믹 내부 에서 산란을 일으키는 요인은 해당 물질과 굴절율이 다 른 이종의 물질들이며, 그 중 가장 투과율에 영향을 크 게 미치는 것은 가장 낮은 굴절율인 1 의 값을 가지는 기 공이다. 특히, 레이저 발진용 세라믹에 요구되는 투명함 의 기준의 경우 이론투과율 대비 $95 \%$ 이상으로 제안되 기도 하였으며 이는 세라믹 내부의 기공이 거의 완전히 제거된 상태를 의미한다. ${ }^{11)}$

빛의 산란을 완전히 억제한다고 해도 결정구조가 등방성 입방정(isotropic cubic) 구조가 아닌 이방성 (anisotropic)을 가지는 세라믹 소재의 경우 결정면 방 향에 따라 굴절률이 미세하게 달라지므로 다결정에서는
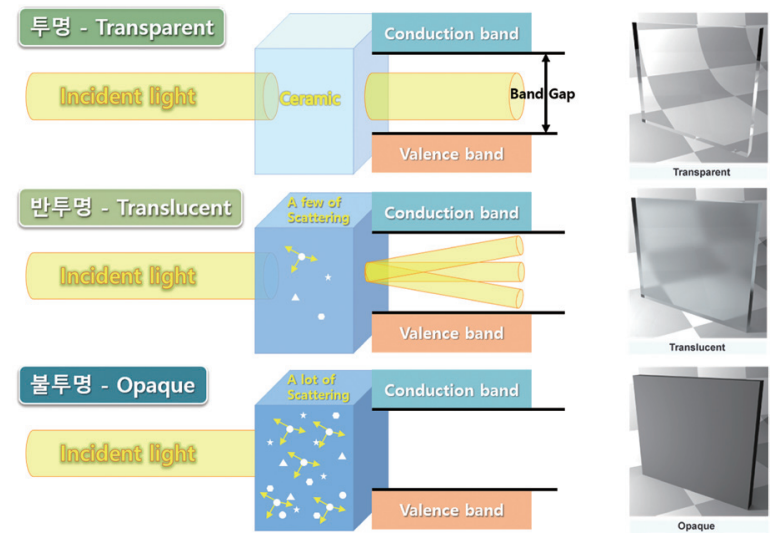

Fig. 6. 투명/반투명/불투명의 개념도


Fig. 7. (a) 이방성 결정의 복굴절 누적에 따른 반투명화 현상 (b) $\alpha-\mathrm{Al}_{2} \mathrm{O}_{3}$ 의 두께에 따른 투명도 차이 ${ }^{12)}$

결정입자 1 개를 지날 때 마다 복굴절 현상이 누적됨으로 인해 직선 투과 특성을 잃어버린다. 이방성 단결정에서 는 아래에 위치한 검은 선이 두 개로 보일 뿐이지만, 이 것이 무수한 작은 다결정으로 누적되면 흐릿하게 번져 서 보이게 되는 것이다. Fig. 7(a)) 대표적인 소재가 알 파 알루미나 $\left(\alpha-\mathrm{Al}_{2} \mathrm{O}_{3}\right)$ 로, 두께가 두꺼워짐에 따라 복굴 절 누적이 심화되어 점차 불투명해지는 특징을 나타낸 다. ${ }^{12)}$ (Fig. 7(b))

\section{3. 례이저 발진용 투명셰라믹의 기술개발 동향}

앞서 언급했듯이, 레이저 발진용 투명세라믹은 이론 투과율 대비 $95 \%$ 의 높은 수준의 투명도를 요구하기 때 문에 1995년에서야 일본의 Ikesue에 의해 해당 수준의 $\mathrm{Nd}: \mathrm{YAG}$ 투명세라믹이 제조되고 최초의 레이저 발진이 보고되었다. 고순도의 $\mathrm{Y}_{2} \mathrm{O}_{3}, \mathrm{Al}_{2} \mathrm{O}_{3}$ 원료분말을 이용하 고 $1800^{\circ} \mathrm{C}$ 의 고온에서 10 시간 이상 진공소결을 통해 투 명한 Nd:YAG 세라믹을 얻을 수 있었으며, Nd:YAG 단 결정에 근접하는 레이저 발진 효율을 갖는 $100 \mathrm{~mW}$ 급 레이저 발진 세라믹(직경 $8 \mathrm{~mm} \mathrm{X}$ 두께 $2 \mathrm{~mm}$ )을 얻었 다. 이를 기점으로 진공소결에 의한 투명세라믹 제조 기 술이 급격하게 발전하여, 2002년 일본의 코노시마 화 학(Konoshima Chemical)과 전기통신대학(University 
of Electro-Communications)의 협동연구에 의해 $1 \mathrm{~kW}$ 급 레이저 발진 $\mathrm{Nd}: Y A G$ 세라믹 시스템(직경 $8 \mathrm{~mm}$ $\mathrm{X}$ 두께 $203 \mathrm{~mm}$ ) 구현에 성공하였다. 이후, 미국의 고 에너지 레이저(HEL) 개발에 대면적 슬라브 형태의 $\mathrm{Nd}: \mathrm{YAG}$ 투명세라믹을 적용하게 되면서 미국의 노스롭 그루먼(Northrop Grumman Corporation), 텍스트론 (Textron Inc.), 로렌스리버모어 국립연구소(Lawrence Livermore National Laboratory, LLNL) 등과 협업하 여 2009년 $100 \mathrm{~kW}$ 급 레이저 발진 Nd:YAG 세라믹 시스 템(120mm X $120 \mathrm{~mm} \mathrm{X} \mathrm{20mm)을} \mathrm{성공적으로} \mathrm{개발하}$ 였다.

전술 고에너지 무기로의 연구개발이 중단된 현재 YAG 투명세라믹 기반 고출력 레이저 발진 시스템은 유 럽의 HiLASE 센터에서 금속/합금의 레이저 피닝(Laser shock peening, LSP) 기술의 혁신을 목표로 다중 슬라 브 $\mathrm{Yb}: \mathrm{YAG}$ 를 적용하여 $100 \mathrm{~J}-10 \mathrm{~Hz}$ 급 이상의 고출력/ 고반복 레이저 개발을 진행하고 있다.

YAG 세라믹은 상대적으로 낮은 열전도도에 의해 레 이저 발진 시 발생되는 열을 제거하는 속도가 느리기 때 문에 내열충격성이 약하고, 열 렌즈 효과(Thermal lens effect)가 나타나기 때문에, 더 높은 레이저 출력에 도 달하기 위해서는 열전도도가 보다 양호한 레이저 발진 세라믹 소재에 대한 요구가 발생하게 되었다. 그 후보 군으로 희토류 삼이산화물(Rare-earth sesquioxide) 의 레이저 발진 세라믹으로 연구가 최근에 많이 이루어 지고 있는 추세이다. $\mathrm{Lu}_{2} \mathrm{O}_{3}, \mathrm{Y}_{2} \mathrm{O}_{3}, \mathrm{Sc}_{2} \mathrm{O}_{3}$ 등을 기반으 로 한 연구가 이루어지고 있는데, 해당 소재들의 일반적 인 열전도도 및 열충격 저항 특성을 표 1에 나타내었다. $\mathrm{YAG}$ 의 경우 열전도도가 낮고, 탄성률이 높기 때문에 열충격 저항성이 낮은 값을 나타낸다. 하지만, 희토류

Table 1. 레이저 발진용 투명세라믹의 열충격 저항성 비교

\begin{tabular}{c|c|c|c|c}
\hline & $\begin{array}{c}\text { 열전도도 } \\
(\mathrm{W} / \mathrm{mK})\end{array}$ & $\begin{array}{c}\text { 열팽창 } \\
\text { 계수 }\end{array}$ & $\begin{array}{c}\text { 탄성율 } \\
(\mathrm{GPa})\end{array}$ & $\begin{array}{c}\text { 열충격 } \\
\text { 저항성 }\end{array}$ \\
\hline $\mathrm{Y}_{2} \mathrm{O}_{3}$ & 13.6 & 7.4 & 173 & $140 \%$ \\
\hline $\mathrm{Sc}_{2} \mathrm{O}_{3}$ & 16.5 & 6.7 & 221 & $160 \%$ \\
\hline $\mathrm{Lu}_{2} \mathrm{O}_{3}$ & 12.5 & 5.5 & 178 & $180 \%$ \\
\hline $\mathrm{YAG}$ & 10.8 & 6.1 & 282 & $100 \%$ \\
\hline
\end{tabular}

삼이산화물의 경우 상대적으로 높은 열전도도/낮은 탄 성률로 인해 $\mathrm{YAG}$ 의 열충격 저항성을 $100 \%$ 라고 할 때 40 80\% 높은 값을 가지기 때문에 레이저 발진용 대면 적 투명세라믹에 보다 적합한 내열 특성을 나타내는 것 이다. 게다가, $\mathrm{YAG}$ 의 경우 크기가 작은 원소인 $\mathrm{Al}$ (이온 반경 $0.56 \AA)$ 이 포함되어 있으므로 인해 $\mathrm{Nd}(0.983 \AA)$, $\mathrm{Yb}(0.868 \AA), \mathrm{Ho}(0.901 \AA), \operatorname{Er}(0.890)$ 등의 레이저 발 진 원소가 도핑될 때 격자 왜곡(lattice distortion)이 $\mathrm{Lu}_{2} \mathrm{O}_{3}, \mathrm{Y}_{2} \mathrm{O}_{3}, \mathrm{Sc}_{2} \mathrm{O}_{3}$ 등 이삼산화물 대비 심하므로 도핑 량 증가에 따른 열전도도의 감소 또한 더 현저하게 나타 나는 문제점이 있다. 즉, 레이저 발진 원소 도핑량이 증 가할 수록 희토류 이삼산화물의 내열 특성이 YAG 대비 우수한 것이다. $\mathrm{Lu}_{2} \mathrm{O}_{3}, \mathrm{Sc}_{2} \mathrm{O}_{3}$ 의 경우 원재료의 희소성 에 기인한 높은 가격으로 인해 활발한 연구는 이루어지 지 않고 있고, 희토류 중 가장 접근성이 좋은 $\mathrm{Y}_{2} \mathrm{O}_{3}$ 기반 레이저 발진용 투명세라믹 연구가 다양하게 이루어지고 있다.

레이저 발진용 $\mathrm{Y}_{2} \mathrm{O}_{3}$ 투명세라믹 연구개발 역시 일 본이 가장 앞서가고 있다. 최초의 $\mathrm{Nd}: \mathrm{YAG}$ 레이저 세 라믹 개발자인 Ikesue가 설립한 월드랩(World Lab. Company) 및 코노시마 화학이 가장 우수한 특성의 $\mathrm{Y}_{2} \mathrm{O}_{3}$ 레이저 세라믹 기술을 보유하고 있다. 그 뒤를 미 국, 중국, 싱가포르 등에서 바짝 쫓아가고 있는 중인데, 2019년 싱가포르 난양공대(Nanyang Technological University)에서 공식적으로 보고된 논문 중에서는 가 장 높은 광투과율 및 레이저 발진 효율을 보고한 바 있 다. ${ }^{13)}$ 미국 해군연구소(Naval Research Laboratory, $\mathrm{NRL}$ )에서도 원료분말의 초고순도화를 통해 이삼산화물 기반 레이저 발진용 투명세라믹을 연구개발에 적극적이 며, 이를 통해 $\mathrm{Yb}: \mathrm{Y}_{2} \mathrm{O}_{3}, \mathrm{Ho}: \mathrm{Lu}_{2} \mathrm{O}_{3}$ 등의 레이저 세라믹 을 개발하는데 성공하였다. ${ }^{14)}$

해당 연구들은 모두 초고순도 원료를 직접 합성하는 것으로 시작하여 $1700^{\circ} \mathrm{C}$ 이상의 고온, 진공 분위기 하에 서 장시간 소결을 함으로써 레이저 발진이 가능한 이삼 산화물 투명세라믹을 제조하고 있다. 하지만, 레이저 발 진이 가능한 수준의 높은 광투과율을 얻는 결정적인 요 인이 무엇인지에 대해서는 정확하게 설명하고 있지 않 


\section{특 집 표 김하늘, 고재웅, 박영조, 오현명, 이현권}

으므로 논문에서 명시한 세라믹 제조 공정을 그대로 따 라한다고 해서 투명세라믹이 쉽게 얻어지는 것은 아니 다. 따라서, 후발 연구자의 입장에서는 시행착오를 통 해 논문에는 나오지 않은 노하우를 스스로 확보해야 하 는 기술적인 진입장벽이 여전히 존재한다. 이러한 진입 장벽으로 인해 미국의 고에너지 레이저 무기 개발사업 및 유럽의 HiLASE 센터 등 레이저 기술 선진국에서조 차 여전히 코노시마 화학의 대면적 슬라브 투명세라믹 을 수입해서 사용하고 있는 실정이다.

\section{4. 국내의 투명셰라믹 연구개발 동향 및 재료연구소의 기술 소개}

국내의 투명세라믹 연구개발은 2000년대 초 반 KAIST에서 X-선 섬광체용 복합 이삼산화물인 $\mathrm{Eu}:(\mathrm{Gd}, \mathrm{Y})_{2} \mathrm{O}_{3}$ 를 개발한 것을 시작으로 2000 년대 중반 영남대학교에서 $\gamma$-AlON 투명세라믹을 연구실 수준에 서 개발하였고, 2010년대 중반에서야 핵심방산소재개발 사업을 통해 산학연이 협동하여 방위산업용 적외선 투 과창 및 투명 방탄창 개발을 목표로 대면적 투명세라믹 제조기술을 본격적으로 개발하기 시작하였다. 하지만, 레이저 발진용 투명세라믹은 최근에서야 재료연구소, KAIST, 한양대학교에서 일부 초기단계의 연구결과가 발표되고 있는 수준에 그치고 있다. 아직 세계 최고 수 준 대비하여 광투과율이 열위에 있으며, 레이저 발진 테 스트도 2019년에 최초로 성공하였을 정도로 선진국 대 비 기술개발이 뒤쳐져 있는 현실이다.

2004년 KAIST에서는 나노분말을 합성하고 열간가압 소결(Hot-press) 공정을 통해 가시광선 투과도가 미약 한 $\mathrm{Eu}:(\mathrm{Gd}, \mathrm{Y})_{2} \mathrm{O}_{3}$ 반투명 세라믹을 보고한 바 있다. ${ }^{15)}$ 당 시에는 국내에 투명세라믹 관련 연구가 전무한 수준이 어서 결과물이 우수하진 않았으나, 연구개발의 시작점 이 되었다는 의미가 있다. 2009년 영남대학교에서 상용 분말을 원료로 다양한 소결첨가제 및 소결조건의 조합 을 통해 가시광 영역에서 광투과율 70\%를 초과하는 투 명한 $\gamma-\mathrm{AlON}$ 세라믹을 보고한 것이 국내 투명세라믹 기술개발의 중요한 이정표라 할 수 있다. ${ }^{16)}$ 이후 재료연
구소에서 2015년부터 현재까지 $\mathrm{Y}_{2} \mathrm{O}_{3}, \mathrm{MgAl}_{2} \mathrm{O}_{4}$ 투명세 라믹 관련 논문을 22편, KAIST에서 $\mathrm{Y}_{2} \mathrm{O}_{3}, \mathrm{Y}_{2} \mathrm{O}_{3} / \mathrm{MgO}$ 투명세라믹 논문을 7편 출판함으로써 국내의 투명세라 믹 기술개발이 급격하게 진전되고 있다. 이하, 레이저 발진용 투명세라믹으로 사용가능한 $\mathrm{Y}_{2} \mathrm{O}_{3}$ 에 대한 국내 기술개발 동향에 대해 정리하고 앞으로 나아가야 할 길 에 대해 이야기하고자 한다.

일반적으로 $\mathrm{Y}_{2} \mathrm{O}_{3}$ 투명세라믹의 소결과정은 기공을 제 거하기 위한 장시간의 진공소결과 그로 인해 발생한 산 소 공공의 회복을 위한 어닐링 공정으로 이루어져 왔 다. 재료연구소에서 처음 시도한 공정 또한 동일한 공정 이다. 진공소결 시 승온속도가 느릴수록 기공이 확산되 어 나가는 시간이 확보되어 입내 기공의 숫자가 줄어듦 으로 인해 투과도가 높아지는 현상을 보고한 바 있다. ${ }^{17)}$ (Fig. 8) 이는 승온속도가 빠를수록 입자성장 속도가 빠 르고, 그로 인한 입계/기공 분리가 더 많이 발생할 수 있 다는 소결이론으로 설명이 가능하다. 따라서, 투명세라 믹 소결 시 입내 기공의 발생을 억제하기 위해서는 승온 속도는 느릴수록 유리하다.

또한, 진공소결 유지시간에 따른 소결체 내부 위치에 따른 미세구조 차이도 밝혀낸 바 있다. $1550 \sim 1600^{\circ} \mathrm{C}$ 온도 범위에서 소결체의 중심부보다 외부환경과 인접한 부위의 입성장이 빠르게 일어나는 현상을 확인하였다. ${ }^{18)}$ (Fig. 9) 이러한 현상의 발생이유에는 두 가지 가능성이

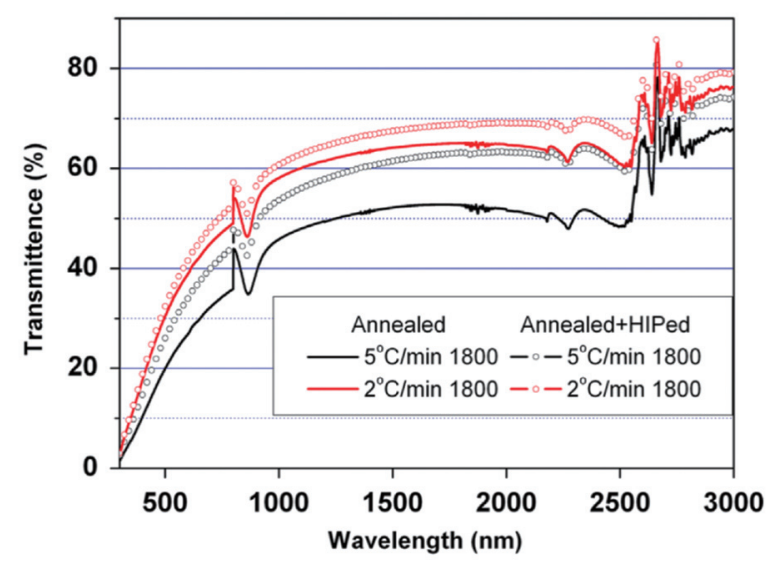

Fig. 8. $\mathrm{Y}_{2} \mathrm{O}_{3}$ 투명세라믹의 진공소결 시 승온 속도의 중요성 ${ }^{17)}$ 


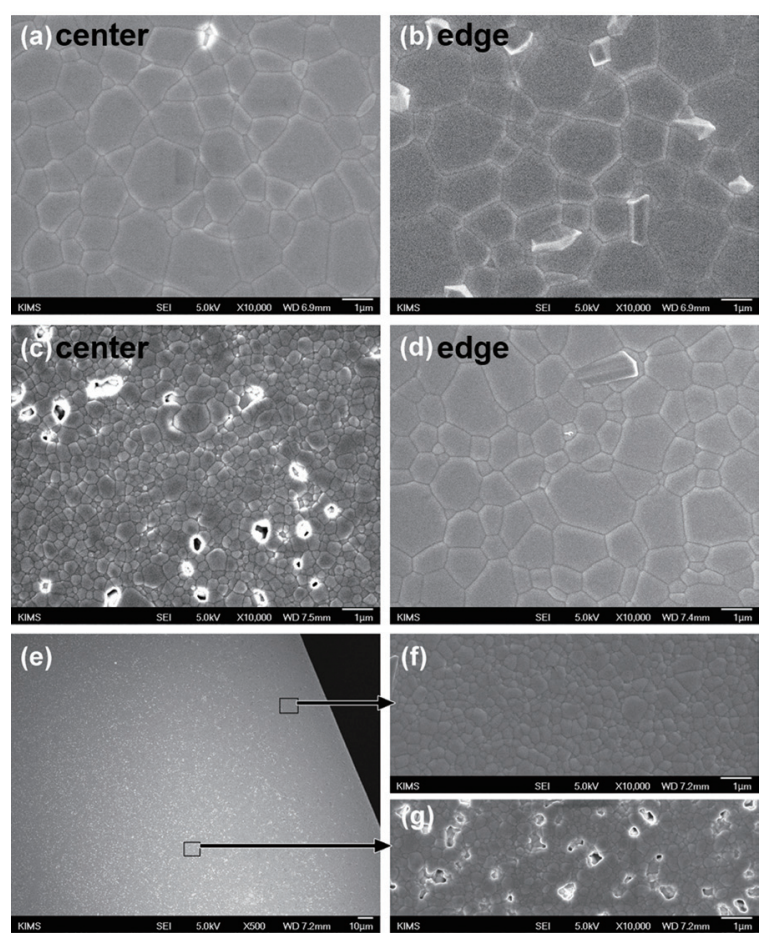

Fig. 9. $\mathrm{Y}_{2} \mathrm{O}_{3}$ 소결 시 온도에 따른 세라믹 중심부/표면부 미세구조 차이 ${ }^{18)}$

있는데, 첫째로 외부환경과 인접한 쪽의 기공의 제거가 더 빠르게 일어남으로 인해 입계 이동 저항이 약해지기 때문일 수 있다. 또 다른 가능성은 외부환경과 인접한 영역의 산소 공공이 내부에 비해 더 많이 발생함으로 인 해 물질확산속도가 빨라지는 것에 기인한 것일 수 있다. 따라서, 고온에서 장시간 진공소결을 하는 경우 소결체 내부의 위치에 따라 입자 크기 차이 및 기공함유량이 국 부적으로 차이가 날 수 있기 때문에 소결온도 및 유지시 간의 적절한 선택이 필요하다.

하지만, 일반적인 진공소결 공정만으로는 소결성이 우수한 나노 원료분말을 사용해도 $1700^{\circ} \mathrm{C}$ 이상의 고온 이 필요할 뿐만 아니라, 고온/진공환경에 의한 $\mathrm{Y}_{2} \mathrm{O}_{3}$ 의 환원으로 산소 공공이 필연적으로 발생하는 문제점이 존재한다. 재료연구소에서는 이를 해결하기 위해 진공 분위기에서 가압을 하여 소결온도를 $100^{\circ} \mathrm{C}$ 이상 낮출 뿐만 아니라, 탄탈럼(Ta) 호일(foil)을 환원 방지막으로 사용함으로써 산소 공공의 회복을 위한 어닐링 공정없



Fig. 10. 재료연구소에서 개발한 $\mathrm{Y}_{2} \mathrm{O}_{3}$ 투명세라믹 소결 공정 ${ }^{19}$

(a)

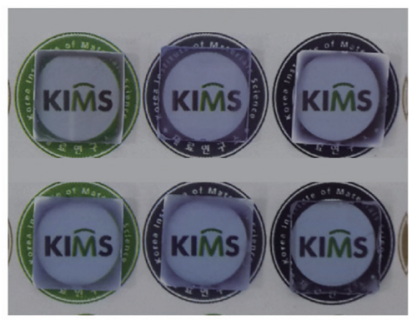

(b)

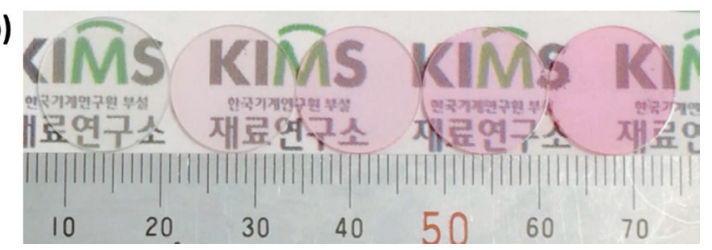

Fig. 11. 재료연구소의 레이저 발진용 투명세라믹 (a) $\mathrm{Nd}: \mathrm{Y}_{2} \mathrm{O}_{3}$ (b) $\mathrm{Er}: \mathrm{Y}_{2} \mathrm{O}_{3}{ }^{21-22)}$

이 1단계 소결 공정만으로 가시광 파장대에서 $74 \sim 80 \%$ 의 높은 광투과율을 가지는 $\mathrm{Y}_{2} \mathrm{O}_{3}$ 투명세라믹 제조에 성 공하였다. ${ }^{19)}$ (Fig. 10) 이와 같이 개발된 공정을 적용하 여 국내 최초로 $\mathrm{Nd}: \mathrm{Y}_{2} \mathrm{O}_{3}$ 투명세라믹의 제조를 2016년 에 보고하였는데, $\mathrm{Nd}$ 첨가에 의한 기공발생을 제어하지 못하여 가시광 영역에서 광투과율이 60 70\%에 범위에 불과하였다. ${ }^{20)}$ 그 후 2018년 소결첨가제 $\mathrm{ZrO}_{2}, \mathrm{La}_{2} \mathrm{O}_{3}$ 를 동시에 첨가하고 첨가제 혼합 비율과 소결 조건의 최 적화를 통해 $\mathrm{Nd}: \mathrm{Y}_{2} \mathrm{O}_{3}$ 투명세라믹의 가시광선 투과율을 74 80\%로 크게 개선하였는데, 이는 $\mathrm{Nd}$ 를 첨가하지 않은 $\mathrm{Y}_{2} \mathrm{O}_{3}$ 투명세라믹과 동등한 수준의 높은 광투과율 이다. ${ }^{21)}$ (Fig. 11(a))대표적인 고체레이저용 발진 원소인 $\mathrm{Nd}$ 이외에도 $\mathrm{Er}: \mathrm{Y}_{2} \mathrm{O}_{3}$ 투명세라믹 또한 진공소결 공정 을 통해 성공적으로 제조하였다. 해당 연구 또한 $\mathrm{ZrO}_{2} /$ $\mathrm{La}_{2} \mathrm{O}_{3}$ 소결첨가제의 최적화를 통해 이루어졌으며, 가 


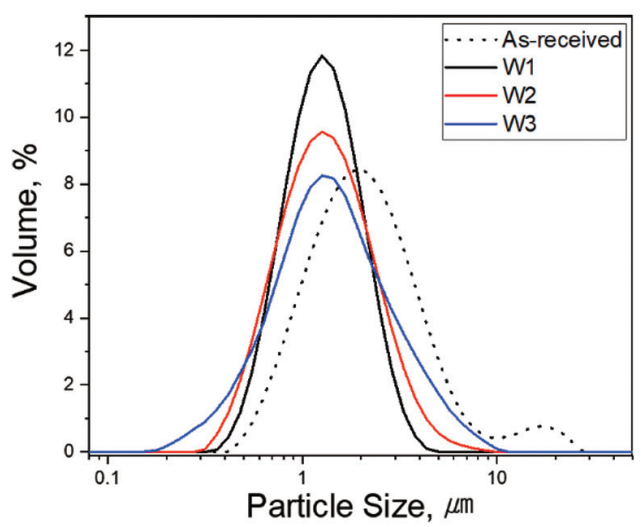

Fig. 12. $\mathrm{Y}_{2} \mathrm{O}_{3}$ 투명세라믹 제조시 초기 원료 입자분포의 중요성 24

시광 파장인 $600 \mathrm{~nm}$ 에서 $81 \%$ 를 웃도는 높은 광투과율 을 획득하였다. ${ }^{22)}$ (Fig. 11(b)) 일반적으로 고체레이저의 높은 발진 효율을 위해서는 광결정의 광투과율이 이론 투과율의 $99 \%$ 이상의 수준이 요구되는 것을 감안할 때, 재료연구소에 개발된 $\mathrm{Nd}: \mathrm{Y}_{2} \mathrm{O}_{3}$ 및 $\mathrm{Er}: \mathrm{Y}_{2} \mathrm{O}_{3}$ 는 고효율 레이저 발진이 가능한 수준에 근접한 것으로 기대되고 있다.

재료연구소의 또 다른 기술적인 성과는 진공소결열간등방압소결(Hot-isostatic press, HIP) 공정을 통 해 소결온도를 $1450^{\circ} \mathrm{C}$ 까지 낮춰 평균입자크기를 0.64 $\mu \mathrm{m}$ 로 미세화시킴으로써 강도 $292 \mathrm{MPa}$, 내열충격지수 (Hasselman mild thermal shock resistance)를 2.41 로 세계최고 내구성을 가지는 $\mathrm{Y}_{2} \mathrm{O}_{3}$ 투명세라믹 제조에 성공한 것이다. 레이저 발진 시 발생하는 열충격에 보다 잘 견딜 수 있는 $\mathrm{Y}_{2} \mathrm{O}_{3}$ 투명세라믹의 제조 방향성을 제시 했다는 측면에서 의미를 가지는 결과이다. ${ }^{23)}$

투명세라믹의 제조는 그야말로 장인 정신이 필요한 분야일 수도 있다. 세라믹 산업 종사자들이 간과하고 넘 어가기 쉬운 조그만 공정 하나조차 최종 결과물에 막대 한 영향을 미친다는 연구결과를 2020년에 발표했는데, 밀링 공정 조건에 따라 원료분말의 입자 분포가 달라지 고 균질한 입자 분포를 가질수록 광투과율이 극적으로 개선된다는 것이다. 원료분말의 볼 밀링 시 어떤 방법을 선택하는지, 그 방법 안에서 공정조건을 어떻게 가져가

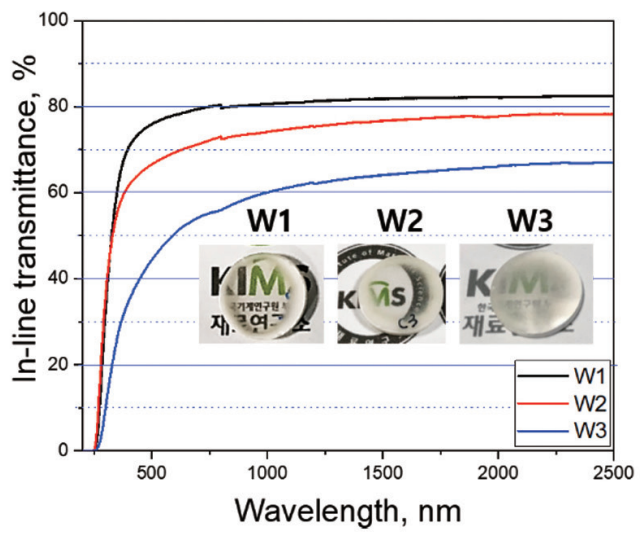

는 지에 따라 마치 나비효과와 같이 가시광선 투과율이 $60 \%$ 미만에서 $80 \%$ 수준까지 큰 차이를 나타냄을 보고 하였다. ${ }^{24)}$

KAIST에서도 $\mathrm{Y}_{2} \mathrm{O}_{3}$ 원료분말의 상태 및 진공소결 시 외부환경의 중요성에 대한 연구결과를 발표하였다. $\mathrm{Y}_{2} \mathrm{O}_{3}$ 나노 분말의 합성 시 하소 온도가 상대적으로 높기 때문에 하소 후 형성된 100 200nm 크기의 입자 1개가 마치 수십 $\mathrm{nm}$ 크기의 다결정이 소결된 것과 같은 미세 구조로 이루어져 있을 뿐만 아니라 나노 크기의 입내기 공이 존재한다는 것을 밝혔다. 이 때, 하소 조건을 저온 의 진공 분위기로 설정해야만 개별 입자의 내부에 존재 하는 초미세 나노기공이 제거되므로 소결 후 투명세라 믹의 광투과율을 높일 수 있다는 결과를 보고하였다. ${ }^{25)}$ 또한, 소결 시 환경에 대해 열역학적으로 고찰한 논문을 보고한 바 있는데, 진공 분위기에서 소결하는 경우 발생 하는 산소 공공을 억제하기 위해 열역학적으로 먼저 산 소 손실이 발생함으로써 소결 중인 $\mathrm{Y}_{2} \mathrm{O}_{3}$ 에 산소를 공급 해 줄 수 있는 지르코니아 $\left(\mathrm{ZrO}_{2}\right)$ 를 $\mathrm{Y}_{2} \mathrm{O}_{3}$ 성형체 외부를 보호하여 산소 공공 발생이 없는 $\mathrm{Y}_{2} \mathrm{O}_{3}$ 투명세라믹을 얻 는데 성공하였다. ${ }^{26)}$ 이는 재료연구소에서 발표한 탄탈럼 호일을 이용한 산소 공공 발생 억제 기술과 일맥상통하 는 것이다.

끝으로, 재료연구소에서 제조한 $\mathrm{Nd}: \mathrm{Y}_{2} \mathrm{O}_{3}$ 투명세라믹 을 가지고 한동대학교에서 전용 레이저 발진 인프라 구 

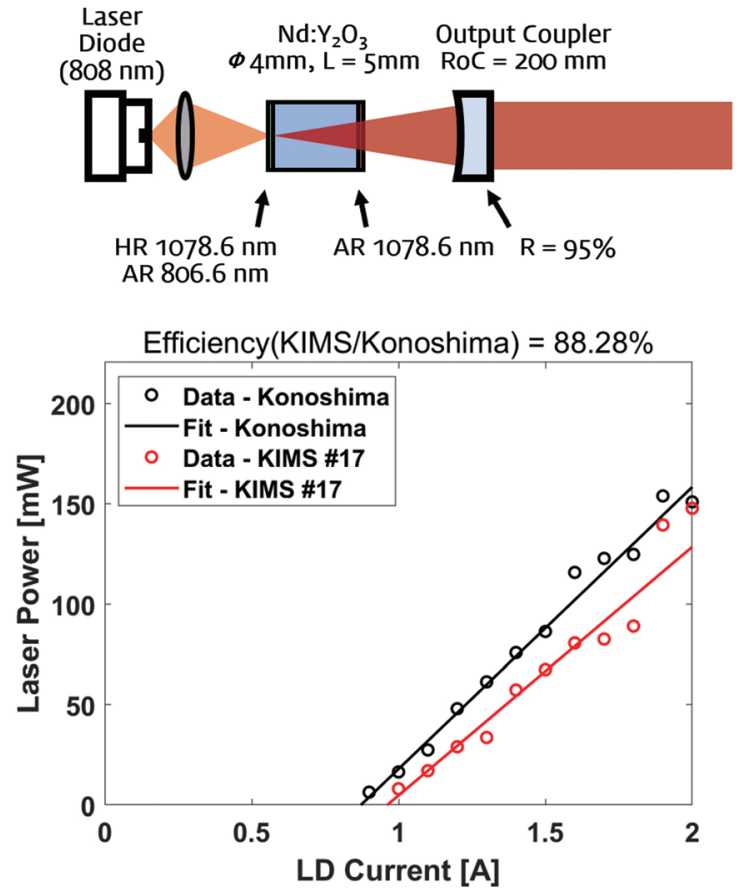

Fig. 13. 재료연구소의 $\mathrm{Nd}: \mathrm{Y}_{2} \mathrm{O}_{3}$ 투명세라믹의 국내 최초 레이저 발 진 구현 ${ }^{27)}$

축하여 국내 최초로 투명세라믹 레이저 발진을 2019년 재료연구소에서 보고하였다. 앞서 언급한 레이저 발진 용 투명세라믹 분야 세계 1 위 업체인 코노시마 화학에서 제조한 $\mathrm{Nd}: \mathrm{Y}_{2} \mathrm{O}_{3}$ 와 동일 시스템에서 발진 테스트를 수 행한 결과 코노시마 화학 대비 $88 \%$ 수준의 레이저 발진 효율을 나타내었다. ${ }^{27)}$ (Fig. 13) 이는 투명세라믹에 대한 본격적인 연구가 시작된 지 5년여 만에 레이저 발진이 가능한 수준의 기술 구축에 성공한 것이며, 국내의 투 명세라믹 연구 수준을 한 단계 도약시킨 결과라고 할 수 있다. 재료연구소에서는 레이저 시스템 연구자와의 지 속적인 협업을 통해 레이저 발진용 투명세라믹 기술을 세계 최고 수준으로 개선하고자 노력하고 있다.

\section{5. 결론}

고체 광결정을 광원으로 하는 고출력 고체레이저는 미래형 요격무기, 개인화기 등 군수 산업분야와 세라 믹 · 금속 가공, $3 \mathrm{D}$ 프린팅, 의료, 및 차세대 핵융합 등
민수 산업분야에 걸쳐 광범위하게 활용될 수 있는 고부 가가치 기술이며, 이를 구현하기 위해서는 핵심 광원 소 재인 희토류 기반 투명세라믹 기술 개발이 필요하다.

국내 레이저 산업의 경우, 레이저 장치의 3대 핵심기 술인 “광학부품, 레이저 발진 광원, 시스템” 중 레이저 발진 광원만은 국내 기술 - 산업 기반이 취약해 거의 전 량 수입에 의존하고 있어 국내의 레이저 원천기술 발전 에 근본적인 한계가 존재한다. 레이저 발진 광원을 투명 세라믹으로 대체하면 다결정의 특징인 대면적 및 형상 자유도가 추가되기 때문에 소재 자체뿐만 아니라 각종 부품이나 전체 시스템의 변화도 수반될 수 있으며, 이는 고출력 고체 레이저의 설계 측면에서 원천특허를 확보 할 수 있는 기회 또한 될 수 있다.

특히, 군사적인 측면에서 레이저 무기는 미국이 연구 개발을 20년 이상 선도하고 있으며, 중국, 일본, 독일, 이스라엘 등이 후발주자로 대규모 연구개발 투자를 지 속 중일 정도로 미래의 전략무기로 각광받고 있다. 국내 의 산학연 협력연구를 통해 대면적 레이저 발진용 투명 세라믹 기술의 자력 개발에 성공할 경우 선진국에 대한 기술종속 탈피 및 3 세계 후발국가들에 무기수출도 가능 할 것으로 기대되므로, 당장의 경제성에 얽매이는 것이 아닌 10년지 대계를 준비하는 차원에서 전략적이고 지 속적인 연구개발 지원이 절실히 요구된다.

\section{REFERENCES}

1. J. Hecht, "Short history of laser development," Opt. Eng., 49091002 (2010).

2. A. Feickert, "U.S. Army Weapons-Related Directed Energy(DE) Programs: Background and Potential Issues for Congress," Congressional Research Service Report, (2018).

3. T.S. Rutherford, W.M. Tulloch, E.K. Gustafson, and R.L. Byer, "Edge-Pumped Quasi-Three-Level Slab Lasers: Design and Power Scaling," IEEE J. Quant. Elec., 36 [2] 205-219(2000)

4. R. Boulesteix, A. Maitre, J.F. Baumard, Y. Rabinovitch, and F. Reynaud, "Light scattering by pores in transparent Nd:YAG ceramics for lasers: correlations 
between microstructure and optical properties," Opt. Exp., 18 [14] 14992-15002 (2010)

5. A. Ikesue, T. Kinoshita, K. Kamata, and K. Yoshida, "Fabrication and optical properties of high-performance polycrystalline Nd:YAG ceramics for solid-state lasers," J. Am. Ceram. Soc., 78 [4] 1033-1040 (1995)

6. J. Lu, K. Ueda, H. Yagi, T. Yanagitani, Y. Akiyama, A.A. Kaminskii, "Neodymium doped yttrium aluminum garnet $\left(\mathrm{Y}_{3} \mathrm{Al}_{5} \mathrm{O}_{12}\right)$ nanocrystalline ceramics-a new generation of solid state laser and optical materials," J. Alloys Compd., 341 [1-2] 220-225 (2002)

7. G. Warwick, "Lasers on Lethal," Aviation week \& Space Technology, (2010)

8. National Ignition Facility, https://lasers.llna.gov

9. S.P. David, V. Jambunathan, A. Lucianetti, and T. Mocek, "Overview of ytterbium based transparent ceramics for diode pumped high energy solid-state lasers," High Power Laser Sci. Eng., 6 [62] 1-10 (2019)

10. S. Banerjee, P.D. Mason, K. Ertel, P.J. Phillips, M.D. Vido, O. Chekhlov, M. Divoky, J. Pilar, J. Smith, T. Butcher, A. Lintern, S. Tomlinson, W. Shaikh, C. Hooker, A. Lucianetti, C. Hernandez-Gomez, T. Mocek, C. Edwards, and J.L. Collier, "100 J-level nanosecond pulsed diode pumped solid state laser," Opt. Lett., 41 [9] 2089-2092 (2016)

11. S. Kochawattana, A. Stevenson, S. Lee, M. Ramirez, V. Gopalan, J. Dumm, V.K. Castillo, G.J. Quarles, G.L. Messing, "Sintering and grain growth in $\mathrm{SiO}_{2}$ doped Nd:YAG," J. Eur. Ceram. Soc., 28 1527-1534 (2008)

12. A. Krell, T. Hutzler, and J. Klimke, "Transmission physics and consquences for materials selection, manufacturing, and applications," J. Eur. Ceram. Soc., 29 207-221 (2009)

13. D. Yin, J. Wang, P. Liu, H. Zhu, B. Yao, Z. Dong, and D. Tang, "Fabrication and microstructural characterizations of lasing grade $\mathrm{Nd}: \mathrm{Y}_{2} \mathrm{O}_{3}$ ceramics," J. Am. Ceram. Soc., $1027462-7468$ (2019)

14. W. Kim, G. Villalobos, C. Baker, J. Frantz, B. Shaw, S. Bayya, B. Sadowski, M. Hunt, B. Rock, I. Aggarwal, and J. Sanghera, "Overview of transparent optical ceramics for high-energy lasers at NRL," Appl. Opt., 54 [31] F210-F220 (2015)

15. Y.K. Kim, H.K. Kim, G. Cho, and D.K. Kim, "Synthesis of Eu-doped $(\mathrm{Gd}, \mathrm{Y})_{2} \mathrm{O}_{3}$ transparent optical ceramic scintillator," J. Mater. Res., 19 [2] 413-416 (2004)

16. B.K. Koo, K.H. Koo, J.H. Kim, I.C. Jung, and J. Lee, "Transparency of AlON fabricated by pressureless reaction sintering using various sintering aids," J. Kor. Ceram. Soc., 46 [4] 392-396 (2009)

17. L. Gan, Y.J. Park, H.N. Kim, J.M. Kim, J.W. Ko, and J.W. Lee, "Effects of pre-sintering and annealing on the optical transmittance of $\mathrm{Zr}$-doped $\mathrm{Y}_{2} \mathrm{O}_{3}$ transparent ceramics fabricated by vacuum sintering conjugated with post-hot-isostatic pressing," Ceram. Int., 41 9622-9627 (2015)

18. L. Gan, Y.J. Park, H.N. Kim, J.M. Kim, J.W. Ko, and J.W. Lee, "Fabrication of submicron-grained IR-transparent $\mathrm{Y}_{2} \mathrm{O}_{3}$ ceramics from commercial nanoraw powders," Ceram. Int., 41 11992-11998 (2015)

19. L. Gan, Y.J. Park, M.J. Park, H.N. Kim, J.M. Kim, J.W. Ko, and J.W. Lee, "Facile Fabrication of Highly Transparent Yttria Ceramics with Fine Microstructures by a Hot-Pressing Method," J. Am. Ceram. Soc., 98 [7] 2002-2004 (2015)

20. L. Gan, Y.J. Park, H.N. Kim, J.M. Kim, J.W. Ko, and J.W. Lee, "Fabrication and microstructure of hot pressed laminated $\mathrm{Y}_{2} \mathrm{O}_{3} / \mathrm{Nd}: \mathrm{Y}_{2} \mathrm{O}_{3} / \mathrm{Y}_{2} \mathrm{O}_{3}$ transparent ceramics," J. Eur. Ceram. Soc., 36 [3] 911-916 (2016)

21. L. Gan, Y.J. Park, L.L. Zhu, H.N. Kim, J.W. Ko, and J.W. Lee, "Highly Transparent Nd-Doped Yttria Ceramics Fabricated by Hot Pressing with $\mathrm{ZrO}_{2}$ and $\mathrm{La}_{2} \mathrm{O}_{3}$ as Sintering Additives," J. Alloys Compd., 763 192-198 (2018)

22. L.L. Zhu, Y.J. Park, L. Gan, S.I. Go, H.N. Kim, J.M. Kim, and J.W. Ko, "Fabrication and characterization of highly transparent Er: $\mathrm{Y}_{2} \mathrm{O}_{3}$ ceramics with $\mathrm{ZrO}_{2}$ and $\mathrm{La}_{2} \mathrm{O}_{3}$ additives," Ceram. Int., 43 13127-13132 (2017)

23. L.L. Zhu, Y.J. Park, L. Gan, H.N. Kim, J.W. Ko, and H.D. Kim, "Fabrication of transparent $\mathrm{Y}_{2} \mathrm{O}_{3}$ ceramics with record-high thermal shock resistance," J. Eur. Ceram. Soc., 38 4050-4056 (2018)

24. H.M. Oh, Y.J. Park, H.N. Kim, J.W. Ko, and H.K. Lee, "Effect of powder milling routes on the sinterability and optical properties of transparent $\mathrm{Y}_{2} \mathrm{O}_{3}$ ceramics," J. Eur. Ceram. Soc., https://doi. org/10.1016/j.jeurceramsoc.2020.08.006

25. W.K. Jung, H.J. Ma, S.W. Jung, and D.K. Kim, "Effects of calcination atmosphere on monodispersed spherical particles for highly optical transparent yttria 
ceramic," J. Am. Ceram. Soc., 100 1876-1884 (2017)

26. W.K. Jung, H.J. Ma, Y.T. Park, and D.K. Kim, “A robust approach for highly transparent $\mathrm{Y}_{2} \mathrm{O}_{3}$ ceramics by stabilizing oxygen defects," Scripta Mater., 137 1-4 (2017)


( 1994 서울대학교 무기재료공학과 학사

( 1996 서울대학교 무기재료공학과 석사

( 2000 동경대학교 재료학과 박사

( 2001-2003 미국 오크리지연구소(ORLN) Post-Doc.

( 2003-현재 한국기계연구원 부설 재료연구소 책임연구원
27. "다결정 세라믹 소재의 투명화 원천기술 개발", 재 료연구소 연구운영비 지원사업 2차년도 연차보고서 (2019)

\section{오 고 재 웅}

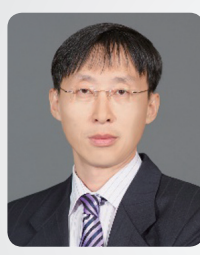

○ 1987 연세대학교 요업공학과 학사

- 1989 서울대학교 무기재료공학과 석사

( 2007 서울대학교 재료공학부 박사

- 1991 일본 금속재료연구소(NRIM) STA Fellow

○ 2001-2002 일본 NIMS 초빙연구원

- 1989-현재 한국기계연구원 부설 재료연구소 책임연구원

\section{○○ 이 현 권}

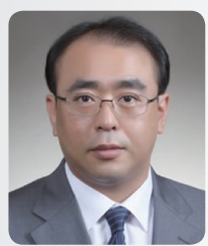

○ 1988 연세대학교 세라믹공학과 학사

( 1990 연세대학교 세라믹공학과 석사

- 2004 연세대학교 세라믹공학과 박사

○ 1993-2002 독일 클라우스탈공과대학 비금속무기재료연구소 전임연구원

- 2004-2010 금오공과대학교 계약교수

( 2010-현재 금오공과대학교 신소재공학부 교수

\section{○○ 오현명}



- 2015 금오공과대학교 신소재공학부 학사

○ 2017 금오공과대학교 신소재공학부 석사

- 2017-현재 금오공과대학교 신소재공학부 박사과정 재학 /

한국기계연구원 부설 재료연구소 학생연구원 